Article

\title{
Evaluation of Fungicides and Management Strategies against Cercospora Leaf Spot of Olive Caused by Pseudocercospora cladosporioides
}

\author{
Joaquín Romero* ${ }^{\mathbb{D}}$, Arantxa Ávila, Carlos Agustí-Brisach ${ }^{\mathbb{D}}$, Luis F. Roca and Antonio Trapero \\ Dpto. de Agronomía, ETSIAM, Universidad de Córdoba, Campus de Rabanales, Edif. C4, 14071 Córdoba, \\ Spain; g32roroj@uco.es (A.Á.); cagusti@uco.es (C.A.-B.); ag3rocal@uco.es (L.F.R.); trapero@uco.es (A.T.) \\ * Correspondence: joaquinromrod@gmail.com; Tel.: +34-957218529
}

Received: 28 January 2020; Accepted: 11 February 2020; Published: 14 February 2020

\begin{abstract}
Cercospora leaf spot of olive (CLSO), caused by Pseudocercospora cladosporioides, is one of the most important foliar diseases of olives worldwide. This study aimed to evaluate the effect of a wide range of fungicides on mycelial growth and conidial germination of P. cladosporioides in vitro, and to evaluate the effect of several fungicides, application timings and management strategies (conservative and risky) to control CLSO under field conditions. Of the studied fungicides, strobilurin compounds and benomyl were the most effective active ingredients, followed by folpet, captan and maneb, in inhibiting mycelial growth and conidial germination. The pyraclostrobin + boscalid treatment was effective under field conditions, even without the application of supplementary copper. Treatments conducted in October or March were more effective than those conducted in May. Management strategies based on the author's experience reduced copper applications up to $32.0 \%$ and $50.0 \%$ (conservative and risky strategy, respectively) in comparison to the reduction with the traditional strategy, without increasing CLSO incidence. This work provides useful information about effective formulations against CLSO and a reduction in unnecessary fungicide applications in an effort to implement IPM in olive orchards under Mediterranean conditions.
\end{abstract}

Keywords: chemical control; fungicide reduction; integrated pest management; Olea europaea; Pseudocercospora cladosporioides

\section{Introduction}

The cultivated olive (Olea europaea subsp. europaea L.) is one of the most important perennial crops across the Mediterranean basin, including Spain [1]. This country contains $25 \%$ of the global olive acreage at approximately $2.6 \mathrm{M}$ ha and nearly $45 \%$ of the global olive oil production. The Andalusia region (southern Spain) is the most important olive-growing region in Spain, representing approximately $65 \%$ and $80 \%$ of the Spanish olive-growing area and production, respectively [2].

Cercospora leaf spot of olive (CLSO) has been described as one of the most relevant diseases of this crop worldwide [1,3-5]. Typical symptoms of CLSO are grey spots and early leaf fall, leading a less shoot growth, a poor fruit production, decreased flower bud formation in the following years, and a delay in fruit ripening [5-8]. Light-green to yellow spots, with may become necrotic, appear on the upper side surface of the leaf, while on the under-side surface, leaden-grey areas also occur with the presence of characteristic lead-black olivaceous asexual fruiting structures [1,3-5]. CLSO symptoms on fruit vary depending on the fruit ripening stage, from brown, sunken, more or less circular areas of three to seven $\mathrm{mm}$ in diameter on green olives to more extensive areas with a pale-yellow halo that surrounds the infected sites on ripening fruits. Severe symptoms cause a decrease in the quality and oil production $[1,5,9-11]$. 
CLSO is caused by Pseudocercospora cladosporioides (Sacc.) U. Braun (syn. Cercospora cladosporioides Sacc.), a fungal pathogen that was first described in olive in 1881 in Italy [12]. From there, P. cladosporioides has been cited in the most important olive-growing areas worldwide [13]. The disease cycle of CLSO has traditionally been compared with that of the olive scab caused by Venturia oleaginea, a polyethic disease. In brief, $V$. oleaginea spread mainly thorough rainfall, occurring infection from 5 to $25^{\circ} \mathrm{C}$. Incubation and conidial production periods are usually long (from $>28$ days to $\approx 9$ months), whilst young leaves are more susceptible to olive scab [14,15]. Regarding CLSO, the few studies previously conducted on the biology of $P$. cladosporioides suggest that the incubation period of CLSO could be even longer (up to 11 months) [5]. The fungus mainly survives on the infected leaves that remain on the tree canopy. Under Mediterranean conditions, lesions enlarge during the autumn, winter and spring, and rainfall initiates conidial spread and new infections, particularly in young, susceptible leaves. Diseased leaves mainly fall to the soil in summer $[5,16]$.

Until now, no specific management strategies are available for olive growers against CLSO. The same traditional strategies developed to control olive scab are usually used to control CLSO. Copper-based compounds or mixtures of these compounds with systemic fungicides, such as difenoconazole, tebuconazole, and strobilurin, have had successful results in controlling olive aerial diseases [17-19]. In fact, copper-based compounds are the most common active ingredient used by olive growers to control foliar diseases [20], mainly due to their relatively low cost, long persistence, efficacy in inhibiting conidial germination and their wide spectrum against fungal and bacterial foliar pathogens [18,20-22]. Copper applications against olive scab and olive anthracnose have been traditionally recommended at the beginning of autumn, in winter (after harvesting and, sometimes, at the end of winter) and at the end of spring [1]. Based on [23], with a phenological growth scale which will be used henceforth in this study, these dates correspond with the following phenological stages (PS): 75-80 (autumn), 81-92 (after harvesting), 5-10 (at the end of winter) and 68-71 (at the end of spring). However, applications of copper-based compounds may present important limitations because their efficacy depends on the application time and their rainfastness [24,25]. Moreover, the long-term use of copper-based compounds in agriculture leads to copper accumulation in the soil surface that leaches into water sources, causing an adverse effect on aquatic or soil organisms and on fertility $[22,26,27]$. Restrictions in the use of copper-based fungicides are expected to be established in the near future to prevent the development of fungicide resistance in crops and possible negative effects on human health [28-30]. Thus, the European Community Directive 128/2009 on the Sustainable Use of Pesticides established mandatory integrated pest management (IPM). Based on this directive, the use of fungicides should be justified based on economic and ecological criteria to reduce or minimize risks to human health and the environment in the framework of IPM [31].

As indicated above, consistent studies about the efficacy of a wide range of fungicides against CLSO under different conditions have not yet been performed. Therefore, the objectives of this study were as follows: (i) to evaluate the effect of copper-based compounds and systemic and organic protective fungicides on the inhibition of mycelial growth and conidial germination in P. cladosporioides by in vitro tests; (ii) to assess the most effective fungicides and their application timing under field conditions; (iii) to evaluate three different management strategies, modifying application timing, in several orchards with endemic populations of $P$. cladosporioides.

\section{Materials and Methods}

\subsection{Fungicides}

Sixteen commercial compounds, including copper-based products (6), systemic (5), and organic preventive (5) fungicides, were evaluated (Table 1). These fungicides were selected based on the active ingredients traditionally used to prevent olive diseases over the last two decades in the main olive growing regions of the world. 
Table 1. Fungicides and dosage used in the different trials carried out in this study.

\begin{tabular}{|c|c|c|c|c|c|c|c|}
\hline \multirow{2}{*}{ Tradename $^{1}$} & \multirow[b]{2}{*}{ Company ${ }^{2}$} & \multirow{2}{*}{$\begin{array}{l}\text { Active Ingredient- } \\
\text { Formulation }^{3}\end{array}$} & \multirow{2}{*}{$\begin{array}{l}\text { Class (FRAC } \\
\text { Number) }^{4}\end{array}$} & \multirow{2}{*}{ Systemic Action } & \multicolumn{3}{|c|}{ Doses (mg L $\left.\mathrm{L}^{-1}\right)$} \\
\hline & & & & & Mycelial Growth & Conidial Germination & $\begin{array}{l}\text { Manufacturer } \\
\text { Recommended }\end{array}$ \\
\hline $\begin{array}{l}\text { Caldo Bordelés } \\
\text { Vallés }\end{array}$ & $\begin{array}{l}\text { Ind. Químicas del } \\
\text { Vallés }\end{array}$ & $\begin{array}{l}\text { Copper calcium sulfate } \\
20 \% \mathrm{WP}\end{array}$ & Inorganic (M1) & No & $50 ; 150 ; 300 ; 600$ & $32 ; 16 ; 8 ; 4 ; 2 ; 1 ; 0.5 ; 0.25 ; 0.12 ; 0.06 ; 0.03 ; 0.01$ & 5000 \\
\hline Copper sulphate & Merk Lab & $\begin{array}{c}\text { Copper sulphate } 25 \% \mathrm{Cu} \\
\text { WP }\end{array}$ & Inorganic (M1) & No & $50 ; 150 ; 300 ; 600$ & $32 ; 16 ; 8 ; 4 ; 2 ; 1 ; 0.5 ; 0.25 ; 0.12 ; 0.06 ; 0.03 ; 0.01$ & 2500 \\
\hline $\begin{array}{l}\text { Cuproflow Caffaro } \\
\text { Blue }\end{array}$ & Caffaro (Isagro) & $\begin{array}{c}\text { Copper oxychloride } 38 \% \\
\text { Cu WP }\end{array}$ & Inorganic (M1) & No & $50 ; 150 ; 300 ; 600$ & $32 ; 16 ; 8 ; 4 ; 2 ; 1 ; 0.5 ; 0.25 ; 0.12 ; 0.06 ; 0.03 ; 0.01$ & 4000 \\
\hline Cuprosan * & Bayer CropScience & $\begin{array}{c}\text { Copper oxychloride } 50 \% \\
\text { Cu WG }\end{array}$ & Inorganic (M1) & No & - & - & 4000 \\
\hline $\begin{array}{c}\text { Funguran-OH } 50 \\
\text { PH }\end{array}$ & Nufarm España & $\begin{array}{l}\text { Copper hydroxide } 50 \% \\
\text { WP }\end{array}$ & Inorganic (M1) & No & $50 ; 150 ; 300 ; 600$ & $32 ; 16 ; 8 ; 4 ; 2 ; 1 ; 0.5 ; 0.25 ; 0.12 ; 0.06 ; 0.03 ; 0.01$ & 4000 \\
\hline Nordox super $75^{*}$ & Nordox & Cuprous oxide $75 \%$ WP & Inorganic (M1) & No & $50 ; 150 ; 300 ; 600$ & $32 ; 16 ; 8 ; 4 ; 2 ; 1 ; 0.5 ; 0.25 ; 0.12 ; 0.06 ; 0.03 ; 0.01$ & 2000 \\
\hline Benomilo 50 & Aragonesas Agro & Benomyl 50\% WP & $\begin{array}{l}\text { B-tubulin inhibitor } \\
\text { (B) (3) }\end{array}$ & Yes & $0.001 ; 0.01 ; 0.1 ; 1 ; 10$ & $32 ; 16 ; 8 ; 4 ; 2 ; 1 ; 0.5 ; 0.25 ; 0.12 ; 0.06 ; 0.03 ; 0.01$ & 900 \\
\hline Bellis * & Basf & $\begin{array}{l}\text { Pyraclostrobin } 10 \%+ \\
\text { Boscalid } 20 \% \text { WG }\end{array}$ & $\begin{array}{l}\mathrm{QoI}^{5}(11)-\mathrm{SDHI}^{6} \\
(7)\end{array}$ & Yes & $0.001 ; 0.01 ; 0.1 ; 1 ; 10$ & $\begin{array}{c}32 ; 16 ; 8 ; 4 ; 2 ; 1 ; 0.5 ; 0.25 ; 0.12 ; 0.06 ; 0.03 ; 0.01 ; \\
0.001 ; 0.0001\end{array}$ & 1000 \\
\hline Flint Max* & Bayer CropScience & $\begin{array}{l}\text { Trifloxystrobin 25\%+ } \\
\text { Tebuconazole 50\% WG }\end{array}$ & $\begin{array}{c}\text { QoI (11)/ } \\
\text { DMI-triazole (3) }\end{array}$ & Yes & - & - & 200 \\
\hline Score $25^{*}$ & $\begin{array}{l}\text { Novartis } \\
\text { (Syngenta) }\end{array}$ & Difenoconazole 25\% EC & DMI ${ }^{7}$-triazole (3) & Yes & $0.001 ; 0.01 ; 0.1 ; 1 ; 10$ & $32 ; 16 ; 8 ; 4 ; 2 ; 1 ; 0.5 ; 0.25 ; 0.12 ; 0.06 ; 0.03 ; 0.01$ & 150 \\
\hline Stroby * & Basf & $\begin{array}{l}\text { Kresoxim- methyl 50\% } \\
\text { WG }\end{array}$ & QoI (11) & Yes & $0.001 ; 0.01 ; 0.1 ; 1 ; 10$ & $32 ; 16 ; 8 ; 4 ; 2 ; 1 ; 0.5 ; 0.25 ; 0.12 ; 0.06 ; 0.03 ; 0.01$ & 750 \\
\hline Belpron F 50 & Probelte & Folpet 50\% WP & Phtalimide (M4) & No & $0.001 ; 0.01 ; 0.1 ; 1 ; 10$ & $32 ; 16 ; 8 ; 4 ; 2 ; 1 ; 0.5 ; 0.25 ; 0.12 ; 0.06 ; 0.03 ; 0.01$ & 3000 \\
\hline Belpron M 80 & Probelte & Maneb $80 \%$ WP & $\begin{array}{c}\text { Carbamate (EBDC) } \\
{ }_{7}(\mathrm{M} 3)\end{array}$ & No & $50 ; 150 ; 300 ; 600$ & $32 ; 16 ; 8 ; 4 ; 2 ; 1 ; 0.5 ; 0.25 ; 0.12 ; 0.06 ; 0.03 ; 0.01$ & 2500 \\
\hline Captazel & $\begin{array}{l}\text { Zeneca Agro } \\
\text { (Syngenta) }\end{array}$ & Captan 50\% WP & Phtalimide (M4) & No & $50 ; 150 ; 300 ; 600$ & $32 ; 16 ; 8 ; 4 ; 2 ; 1 ; 0.5 ; 0.25 ; 0.12 ; 0.06 ; 0.03 ; 0.01$ & 3000 \\
\hline Cobreline Folpet * & C. Q. Masso & $\begin{array}{c}\text { Folpet } 30 \%+\text { Cuprous } \\
\text { oxide } 10 \%+\text { Copper } \\
\text { calcium sulfate } 10 \% \mathrm{WP}\end{array}$ & $\begin{array}{l}\text { Phtalimide (M4)- } \\
\text { Inorganic (M1)- } \\
\text { Inorganic (M1) }\end{array}$ & No & $0.001 ; 0.01 ; 0.1 ; 1 ; 10$ & $32 ; 16 ; 8 ; 4 ; 2 ; 1 ; 0.5 ; 0.25 ; 0.12 ; 0.06 ; 0.03 ; 0.01$ & 2500 \\
\hline Dithane M45 & $\begin{array}{l}\text { Rohm and Haas } \\
\text { (Dow) }\end{array}$ & Mancozeb 80\% WP & $\begin{array}{l}\text { Carbamate (EBDC) } \\
8 \text { (M3) }\end{array}$ & No & $50 ; 150 ; 300 ; 600$ & $32 ; 16 ; 8 ; 4 ; 2 ; 1 ; 0.5 ; 0.25 ; 0.12 ; 0.06 ; 0.03 ; 0.01$ & 4000 \\
\hline
\end{tabular}

${ }^{1}$ All fungicides were tested for in vitro sensitivity tests excepting Cuprosan and Flint Max. ${ }^{2}$ Company names during the Trials development and currently (in brackets). ${ }^{3}$ WP, wettable powder; WG, water dispersible granule; EC, emulsifiable concentrate; EW, emulsion oil in water; SL, soluble. ${ }^{4}$ Group numbers are assigned by the Fungicide Resistance Action Committee (FRAC) according to different modes of actions (for more information, see http://www.frac.info/). ${ }^{5} \mathrm{QoI}=$ quinone outside inhibitor (strobilurin). ${ }^{6}$ SDHI $=$ Succinate dehydrogenase inhibitor. ${ }^{7} \mathrm{DMI}=$ demethylation $\left(\right.$ sterol) inhibitor. ${ }^{8} \mathrm{EBDC}=$ ethylene bisdithiocarbamate. ${ }^{*}$ Products tested under field conditions. 


\subsection{In Vitro Evaluation of Fungicides}

\subsubsection{Inoculum Sources}

Fungal mycelia. The isolate P. cladosporioides ILE40 [5] was used to evaluate the effect of fungicides on mycelial growth. It was recovered from olive leaves of cultivar (cv.) Lechín de Sevilla showing typical symptoms of CLSO. The isolate ILE40 was stored at $5{ }^{\circ} \mathrm{C}$ in darkness inside $50 \mathrm{ml}$ tubes of potato dextrose agar (PDA) (Difco Laboratories ${ }^{\circledR}$, Detroit, MI, USA) filled completely with sterile paraffin oil and maintained in the fungal collection of the Agronomy Department at the University of Córdoba, Spain. Prior to use, a small mycelial plug of the colonized agar was transferred from the collection tube to the PDA acidified with lactic acid [ $25 \%$ ( $\mathrm{vol} / \mathrm{vol})$ at $2.5 \mathrm{ml} \mathrm{l}^{-1}$ of medium, APDA] to minimize bacterial growth. Culture was incubated at $20 \pm 2{ }^{\circ} \mathrm{C}$ with a 12 -h photoperiod of fluorescent light $\left(350 \mu \mathrm{mol} \mathrm{m}^{-2} \mathrm{~s}^{-1}\right)$ for 4 weeks.

Conidial suspensions. To evaluate the effect of fungicides on conidial germination, conidial suspensions of $P$. cladosporioides were obtained by scraping olive leaves with CLSO symptoms. The infected leaves were collected from olive trees of cv. Picudo growing at the "World Olive Germplasm Bank" (WOGB) of the Andalusian Institute for Research and Formation in Agriculture and Fishery (IFAPA in Spanish), located in Córdoba Province (Andalusian region, southern Spain). No fungicides had been applied in this experimental field for the previous three years. Conidia were collected from the leaf surface with a sterile needle and introduced into a sterile tube filled with $2 \mathrm{ml}$ of sterile distilled water (SDW). The resulting conidial suspension was adjusted to $2 \times 10^{5}$ conidia ml ${ }^{-1}$ using a haemocytometer to obtain a final concentration of $10^{5}$ conidia $\mathrm{ml}^{-1}$ after fungicide addition (see below).

\subsubsection{Effect of Fungicides on Mycelial Growth}

The required amounts of each fungicide were calculated according to the active ingredient, and they were added to sterilize PDA $\left(120^{\circ} \mathrm{C}-20 \mathrm{~min}\right)$ at approximately $45^{\circ} \mathrm{C}$ to achieve the required concentrations (Table 1) [32]. Mycelia agar plugs (5 $\mathrm{mm}$ in diameter) obtained from the margins of 14-day-old actively growing culture were placed in the center of Petri dishes $(90 \mathrm{~mm}$ in diameter) containing PDA amended with the compound and doses under evaluation. Non-amended PDA plates were included as a control. There were four replicated Petri dishes per fungicide concentration. Plates were incubated at $20 \pm 2{ }^{\circ} \mathrm{C}$ with a 12-h photoperiod of fluorescent light $\left(350 \mu \mathrm{mol} \mathrm{m}^{-2} \mathrm{~s}^{-1}\right)$ for four weeks in a completely randomized design. The experiment was conducted twice.

The diameter of each colony was measured twice perpendicularly. Measurements were made at the same time and averaged. The diameter was expressed in $\mathrm{mm}$ of real growth by deducting $5 \mathrm{~mm}$ of the initial mycelial plug (growth rate: $\mathrm{mm} \mathrm{day}^{-1}$ ).

\subsubsection{Effect of Fungicides on Conidial Germination}

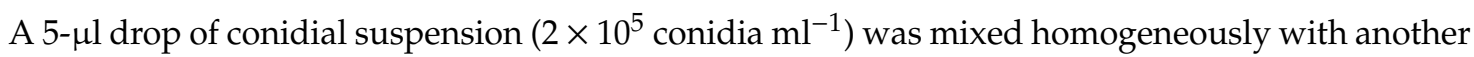
5 - $\mu$ l drop of fungicide solution on a microscope coverslip $(20 \times 20 \mathrm{~mm})$. Coverslips were placed inside the Petri dishes containing water agar, which were used as humid chambers. Dishes were incubated for $48 \mathrm{~h}$ at $20 \pm 2{ }^{\circ} \mathrm{C}$ with a 12 -h photoperiod of fluorescent light. Conidia germination was stopped by staining with acid fuchsin in lactophenol. The germination percentage was determined by evaluating 100 conidia randomly selected on each coverslip. Overlapped conidia and conidia linked to conidiophores were not considered. There were three replicated coverslips per fungicide concentration. The experiment was conducted twice.

\subsection{Effect of Fungicides and Annual Timing on Disease Incidence in a Naturally Infected Orchard}

Two experiments (Trials I and II) were carried out in a commercial olive orchard of cv. Hojiblanca (204 trees/ha; 15 years old) located in 'La Roda de Andalucía' (37.216923, -4.793416; Province of Sevilla, Andalusian region, southern Spain; Figure 1). This orchard was naturally infected by P. cladosporioides, 
with trees showing typical symptoms of CLSO. The experiments were conducted from March 2003 to May 2004.

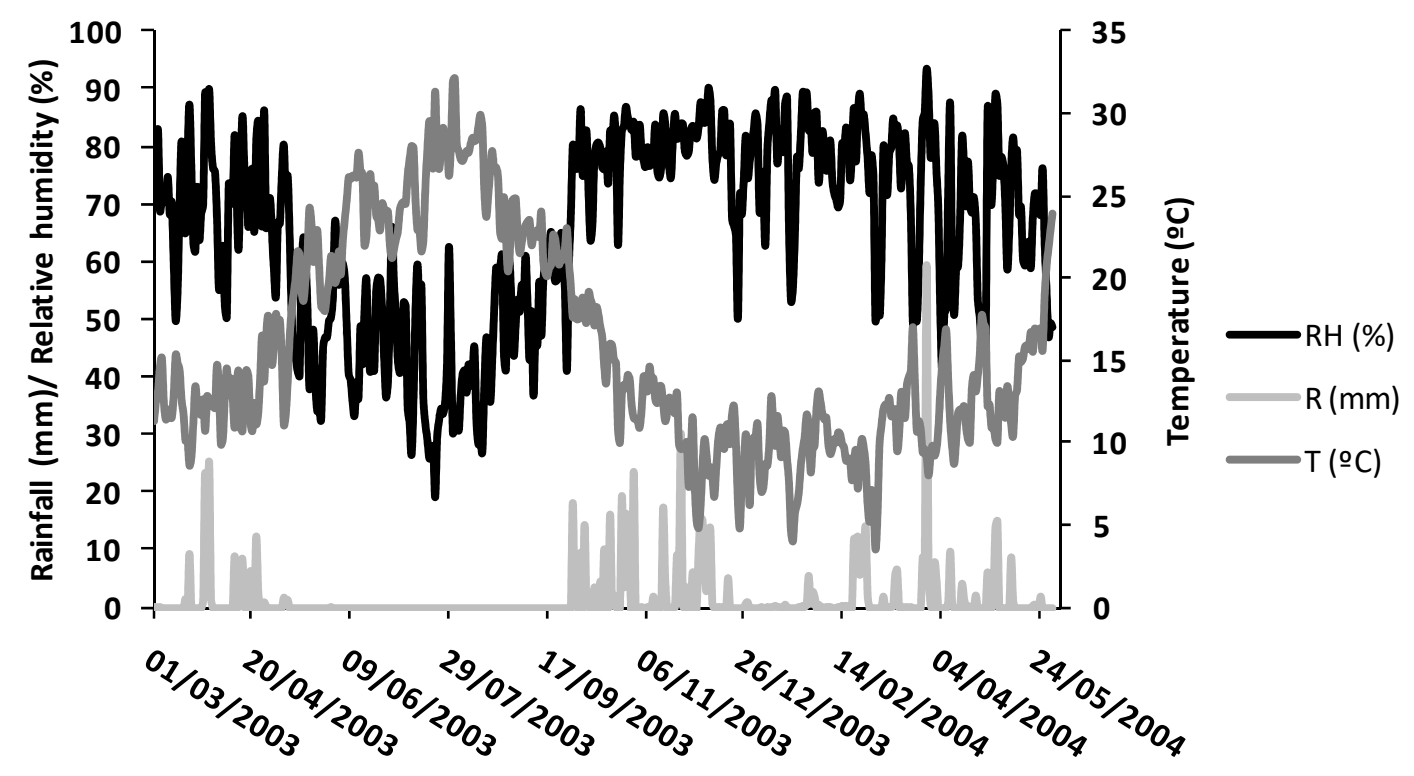

Figure 1. Rainfall ( $R$, light grey line), relative humidity ( $R H$, black line) and air temperature ( $T$, dark grey line) in Sierra de Yeguas (Málaga), the location with the closest meteorological station from the location of the Trials II and III (15 km away). Meteorological data were registered from 1 March 2003 to 31 May 2004.

Trial I. The efficacy of one copper compound (cuprous oxide), three systemic (pyraclostrobin + boscalid, difenoconazole and kresoxim-methyl) fungicides and one protectant (folpet + cuprous oxide + copper calcium sulfate) fungicide was evaluated at the manufacturers' recommended doses (Table 1). Three applications were performed (March 2003, May 2003 and October 2003; PS = 75-80, 5-10 and 68-71, respectively), and the following treatments were conducted: (i) cuprous oxide; (ii) folpet + cuprous oxide + copper calcium sulphate; (iii) difenoconazole + cuprous oxide; (iv) kresoxim-methyl + cuprous oxide; and (v) pyraclostrobin + boscalid. Fungicide applications were carried out by a backpack 25-L sprayer (Synergy $25.6 \mathrm{~cm}^{3}$, Spain). Three liters of fungicide solution were applied per olive canopy to reach homogenous wetting. Treatments were arranged in a completely randomized design with seven blocks and one tree per block. Olive trees sprayed with water were included as controls. The experiment was repeated once in a second experimental field within the same orchard.

Trial II. The effect of annual fungicide application timing was evaluated using cuprous oxide at the manufacturer's dose. Timing was established according to previous experience in controlling olive scab [1]. The following seven application timings were evaluated: (i) a single annual application at three different times-March (PS = 75-80), May (PS = 5-10) and October (68-71); (ii) two annual applications (March + May, March + October and May + October); (iii) three annual applications (March + May + October). March application in 2004 was not carried out. Olive trees without any spraying were included as controls. Fungicide applications were conducted as described above, with the same experimental design as Trial $I$.

Disease assessment. CLSO incidence was evaluated at four different times during the experiment (May and November 2003; March and May 2004) by estimating the percentage of symptomatic leaves using a 0 -to-10 rating scale adapted from fruits to leaves [33]. This scale estimates the percentage of leaves affected by CLSO in each tree according to the following intervals for each scale value: $0=$ no visible symptoms, $1=0.01 \%$ ( $1-3$ affected leaves per tree), $2=0.1 \%$ (5-10 affected leaves per tree), $4=5 \%, 6=25 \%, 8=75 \%$ and $10=$ trees with more than $90 \%$ of leaves showing symptoms. Then, the 
scale data were transformed into the proportion of affected leaves using a logistic equation, where $\mathrm{X}$ is the scaling rating value and $\mathrm{Y}$ is the percentage of CLSO incidence [33].

$$
Y=\frac{1}{1+3^{(7-X)}}
$$

\subsection{Comparative Effectiveness of the Three Management Strategies for Disease Control}

\subsubsection{Management Strategies}

Based on previous knowledge about the epidemiology and control of olive scab and olive anthracnose [1,34-36], two management strategies (conservative and risky) were designed by the authors to compare their efficacy in controlling CLSO against the traditional management strategy conducted by local olive growers (Figure 2). The traditional management strategy consisted of applications with only copper oxychloride (50\%) (Table 1), which were conducted according to the experience of the Andalusian olive growers: three fungicide applications (FA) per year in autumn (PS $=75-80)$, post-harvest $(\mathrm{PS}=85-92)$ and in spring $(\mathrm{PS}=37-50)$.

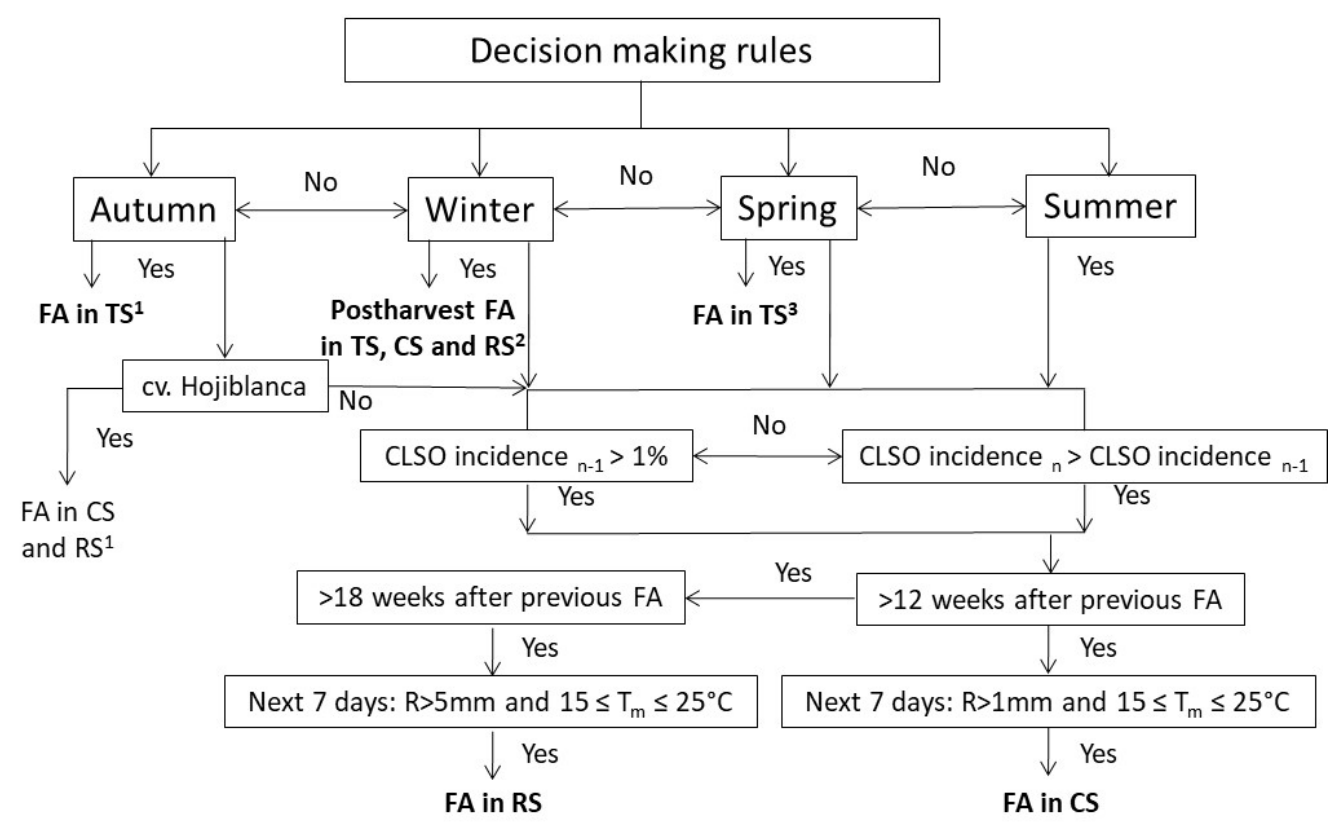

Figure 2. Decision making rules for fungicide application (FA) of traditional, conservative and risky strategies (TS, CS and RS, respectively). ${ }^{1}$ Autumn applications in TS or CS/RS in cv. Hojiblanca orchards were applied during the first half of October (phenological growth stage $=75-80$ based on [23]). ${ }^{2}$ Postharvest applications in TS/CS and RS were applied $<3$ days after fruit harvesting (from November to December, phenological growth stage $=85-92$ [23]). ${ }^{3}$ Spring applications in TS were applied in April-May (phenological growth stage = 37-50 [23]). Rest of fungicides applications were not dependent on disease and weather conditions.

Five decision-making rules were established to perform the two management strategies of the authors, with slight changes between them. Four of the five rules needed to occur simultaneously to support the FAs. In the conservative management strategy, FAs in spring and autumn were conducted when (i) the CLSO incidence of the last evaluation ( $n$, in March-April, see below) was $\geq 1 \%$, or (ii) when an increase in CLSO incidence was observed between the $n-1$ and $n$ evaluations $\left(\mathrm{CLSO}_{\text {incidence }} \mathrm{n}\right.$ $>\mathrm{CLSO}_{\text {incidence n-1 }}$ ). When at least one of these two conditions occurred, (iii) from the 12th week after the last FA, decisions considered the combination of the following two environmental conditions based on the weather forecast for the following seven days-(iv) accumulated rainfall ( $>1 \mathrm{~mm}$ ) and (v) mild average temperatures $\left(15 \leq \mathrm{T} \leq 25^{\circ} \mathrm{C}\right)$. The same rules were established for the risk 
management strategy, except for slight changes in conditions (iii) and (iv) during autumn-more than 18 weeks should have elapsed since the last FA, and the accumulated rainfall must be higher than $5 \mathrm{~mm}$. These changes in the management strategies were not employed in orchards of cv. Hojiblanca because of its high susceptibility to olive anthracnose in autumn [1], so the same decision rules were employed for both management strategies for this cv. In addition, for all management strategies, a copper fungicide was applied in winter immediately after harvest to control olive knot caused by Pseudomonas savastanoi pv. savastanoi. A copper compound (copper oxychloride $50 \%$ ) and a systemic fungicide (trifloxystrobin + tebuconazole) (Table 1) were both applied as part of the FAs in autumn/winter and spring, respectively, in both management strategies (see below the exception in the organic farming system). Weather forecasts were obtained from the nearest area provided by the Spanish Agency of Meteorology (AEMET).

\subsubsection{Experimental Design}

Sixteen commercial orchards of the olive cvs. Arbequina, Hojiblanca, Manzanilla de Sevilla and Picual affected by CLSO were selected across the Andalusia region and southeastern Portugal (Table 2). Experimental orchards ranged from 5 to 20 years old and were located in Córdoba (5 orchards), Jaén (4 orchards), Málaga (3 orchards), Sevilla (3 orchards) (Andalusia region, Southern Spain), and Beja (1 orchard) (South Portugal). Two orchards, one from Sevilla and another from Jaén, were grown within an organic farming system. In these later experimental orchards, the systemic fungicide was not used, and only the copper fungicide was applied. In all the orchards, olive trees were planted on 7-12 × 7-12 m and 7-3 × 1.5 m row spacing in low, high and super-high-density plantations, respectively. The selected orchards were managed according to the cultural practices used in commercial olive orchards in Andalusia [36]. Treatments were arranged in a randomized complete block design with four replicated blocks, with 15 trees per experimental unit arranged in three rows of five trees each. A 20001 sprayer (Mañez-Lozano; $20 \mathrm{~kg} \mathrm{~cm}^{-2}$ pressure, $1.2 \mathrm{~mm}$ nozzles, Spain) was used for FA, which was carried out only under calm, sunny conditions, and 4001 of fungicide solution was applied per treatment in each management strategy $\left(12001 \mathrm{ha}^{-1}\right)$, reaching a homogenous wetting of the olive canopy. The amount of deposited copper in the leaves was measured [37] annually to check the homogeneity of the FA. From April 2012 to August 2016, four epidemical seasons were evaluated. Only the three central trees were evaluated to avoid a possible effect of fungicide drift. The CLSO incidence was annually assessed when the highest CLSO incidence occurred frequently (March-April) by using the same 0 to-10 rating visual scale described above (Moral and Trapero, 2009) [33]. 
Table 2. Olive orchards selected to compare management strategies.

\begin{tabular}{|c|c|c|c|c|c|c|c|}
\hline \multicolumn{2}{|c|}{ Orchard } & \multirow{2}{*}{$\begin{array}{c}\text { Location } \\
\text { Córdoba (Córdoba) }\end{array}$} & \multirow{2}{*}{$\begin{array}{c}\text { UTM }^{1} \\
37.763166 ;-4.670026\end{array}$} & \multirow{2}{*}{$\begin{array}{c}\text { Farming System }^{2} \\
\text { Low-density/Organic }\end{array}$} & \multirow{2}{*}{$\begin{array}{c}\text { Cultivar } \\
\text { Picual }\end{array}$} & \multirow{2}{*}{$\begin{array}{c}\underset{3}{\text { Risk Factor }} \\
\text { Low }\end{array}$} & \multirow{2}{*}{$\begin{array}{c}\begin{array}{c}\text { Period of } \\
\text { Evaluation }\end{array} \\
2012 / 2016\end{array}$} \\
\hline 1 & El Cañuelo & & & & & & \\
\hline 2 & El Realengo $1^{4}$ & Antequera (Málaga) & $37.188711 ;-4.573885$ & High-density/IPM & Arbequina & Mild & $2012 / 2016$ \\
\hline 3 & El Realengo 2 & Antequera (Málaga) & $37.191442 ;-4.576739$ & High-density/IPM & Hojiblanca & Mild & $2012 / 2016$ \\
\hline 4 & El Realengo 3 & Antequera (Málaga) & $37 ., 191959 ;-4.576605$ & High-density/IPM & Picual & Mild & $2012 / 2016$ \\
\hline 5 & Fonte dos Frades & Beja (Portugal) & $38.021307 ;-7.747067$ & High-density/IPM & Hojiblanca & High & $2012 / 2013$ \\
\hline 6 & La Veguilla & Córdoba (Córdoba) & $37.820535 ;-4.896576$ & High-density/IPM & Hojiblanca & Low & $2012 / 2016$ \\
\hline 7 & Linares & Linares (Jaén) & $38.097234 ;-3.709578$ & High-density/IPM & Picual & Mild & $2012 / 2016$ \\
\hline 8 & Los Cansinos & Córdoba (Córdoba) & $37.892221 ;-4.596169$ & Super-High-density/IPM & Arbequina & Low & $2012 / 2015$ \\
\hline 9 & Malena de Castro & Linares (Jaén) & $38.113009 ;-3.590850$ & High-density/IPM & Picual & Low & $2012 / 2016$ \\
\hline 10 & Naranjilla & Carmona (Sevilla) & $37.409752 ;-5.807546$ & High-density/IPM & $\begin{array}{l}\text { Manzanilla de } \\
\text { Sevilla }\end{array}$ & High & $2012 / 2015$ \\
\hline 11 & Ribera Alta & Córdoba (Córdoba) & $37.953271 ;-4.624638$ & High-density/IPM & Picual & High & $2012 / 2016$ \\
\hline 12 & Todolivo & Pedro Abad (Córdoba) & $37.959700 ;-4.466828$ & Super-High-density/IPM & Arbequina & Mild & $2012 / 2015$ \\
\hline 13 & Aljarafe & $\begin{array}{l}\text { Bollullos de la Mitación } \\
\text { (Sevilla) }\end{array}$ & $37.356450 ;-6.164204$ & High-density/Organic & $\begin{array}{l}\text { Manzanilla de } \\
\text { Sevilla }\end{array}$ & High & $2013 / 2016$ \\
\hline 14 & Los Ballesteros & El Cuervo (Sevilla) & $36.795540 ;-5.971842$ & High-density/IPM & Hojiblanca & High & $2013 / 2016$ \\
\hline 15 & $\begin{array}{c}\text { Cortijo de } \\
\text { Guadiana } 1^{4}\end{array}$ & Úbeda (Jaén) & $37.914793 ;-3.232109$ & High-density/IPM & Picual & Mild & $2014 / 2016$ \\
\hline 16 & $\begin{array}{c}\text { Cortijo de } \\
\text { Guadiana } 2\end{array}$ & Úbeda (Jaén) & $37.902171 ;-3.237424$ & High-density/Organic & Picual & Low & $2014 / 2016$ \\
\hline
\end{tabular}

${ }^{1}$ Universal Transverse Mercator coordinate system. ${ }^{2}$ Categories of farming system based on planting density and type of production: Low-density plantation $<100$ olive trees/ha, High-density plantation $\geq 100$ and $<200$, and Super-High-Density plantation $\geq 200$. IPM: integrated pest management. ${ }^{3}$ Risk categories to the infection of aerial olive diseases according to the climatic history of the location (AEMET, 2011) and the particular edaphic and climatic conditions of the experimental field (topography, orientation and presence of rivers and streams nearby). ${ }^{4}$ Within these orchards, different experimental trials were selected depending on the cultivar (El Realengo) or the farming system (Cortijo de Guadiana). 


\subsection{Data Analyses}

For each fungicide concentration and dose, inhibition of mycelial growth and conidial germination was calculated as a percentage with respect to the control treatment according to the following formulas: relative growth inhibition $(\mathrm{RGI})=\left[\left(D_{\text {control }}-D_{\text {Treatment }}\right) / D_{\text {control }}\right] \times 100$, where $D=$ diameter of the fungal colony and relative germination inhibition $(\mathrm{RGeI})=\left[\left(G e_{\text {control }}-G e_{\text {Treatment }}\right) / G e_{\text {control }}\right] \times 100$, where $\mathrm{Ge}=$ conidial germination (\%). Probit regression analysis was used to calculate the concentration that inhibited mycelial growth and conidial germination by $50 \%\left(\mathrm{EC}_{50}\right)$ and $90 \%\left(\mathrm{EC}_{90}\right)$. Analysis of variance (ANOVA) was performed on $\mathrm{EC}_{50}$ and $\mathrm{EC}_{90}$ data, and means were compared using Fisher's protected least significant difference (LSD) test at $p<0.05$ [38].

To evaluate the efficiency of different fungicides, the area under the disease progress curve (AUDPC) was calculated by trapezoidal integration of CLSO incidence over time. The reduction in CLSO incidence (\%) between the first and last evaluation and the AUDPC were subjected to ANOVA, and the treatment means were compared according to the LSD test at $p=0.05$. To evaluate the annual timing of fungicide application, the reduction in CLSO incidence (\%) was subjected to ANOVA, and the treatment means were also compared according to the LSD test at $p=0.05$. To compare management strategies, an index of fungicide application efficacy (IFAE) was calculated as the percentage of healthy tissue (100-CLSO incidence) divided by the number of FAs. The IFAE of conservative and risky strategies was divided by the IFAE of the traditional strategy to obtain the relative IFAE (RIFAE). ANOVA was conducted to determine the differences between management strategies (independent variable) using the CLSO incidence, FA, FA copper-based, IFAE and RIFAE as dependent variables. To compare the reduction in FA only with copper-based compounds, data for the ecological orchards were not considered because only copper-based compounds were allowed there. The averages of the three management strategies were compared by LSD or Dunnett tests at $p=0.05$. The last test was used to compare the CLSO incidence of conservative and risky strategies against the traditional strategy in each orchard and year. When the experiments were repeated, the data were combined after checking the homogeneity of the experimental error variances by the $\mathrm{F}$ test. For ANOVA performance, in all cases, data were tested for normality, pattern of residuals and homogeneity of variances, which indicated their suitability for the statistical analysis without data transformations in all experiments. Data were logarithmically transformed when necessary. Statistical analysis was performed using SPSS (LeOra Software Inc., Berkeley, CA, USA, 2008) and Statistix 10 (Analytical software, Tallahassee, FL, USA, 2013).

\section{Results}

\subsection{In Vitro Evaluation of Fungicides}

\subsubsection{Effect of Fungicides on Mycelial Growth}

Probit regression analysis showed high $\mathrm{EC}_{50}$ values for all copper-based compounds, ranging from 111.8 to $>600 \mathrm{mg} \mathrm{L}^{-1}$ for copper hydroxide and copper sulphate, respectively. A broad range of $\mathrm{EC}_{50}$ values was observed for the organic compounds, ranging from 2.7 to $>600 \mathrm{mg} \mathrm{L}^{-1}$ for folpet and captan, respectively. Concerning the systemic fungicides, very low $\mathrm{EC}_{50}$ values were obtained, ranging from $0.1 \mathrm{mg} \mathrm{L}^{-1}$ for benomyl and pyraclostrobin + boscalid to $2.1 \mathrm{mg} \mathrm{L}^{-1}$ for difenoconazole. The $\mathrm{EC}_{90}$ values of mycelial growth inhibition were always above the higher dosage tested, with the exception of benomyl, mancozeb and copper hydroxide (Table 3). 
Table 3. Effect of fungicides on the inhibition of mycelial growth and conidial germination of Peudocercospora cladosporioides in in vitro sensitivity tests. The pathogen isolate ILE40 and a conidial suspension from olive leaves with disease symptoms were used, respectively, in each of the two trials.

\begin{tabular}{|c|c|c|c|c|}
\hline \multirow{3}{*}{ Fungicides $^{1}$} & \multicolumn{4}{|c|}{ Inhibition } \\
\hline & \multicolumn{2}{|c|}{ Mycelial Growth } & \multicolumn{2}{|c|}{ Conidial Germination } \\
\hline & $\mathrm{EC}_{50}{ }^{2}$ & $\mathrm{EC}_{90}{ }^{3}$ & $\mathrm{EC}_{50}$ & $\mathrm{EC}_{90}$ \\
\hline Copper hydroxide $50 \%$ Cu WP & $111.82 b^{4}$ & $400.41 \mathrm{a}$ & $0.85 \mathrm{~cd}$ & $15.03 \mathrm{a}$ \\
\hline Copper oxychloride $38 \% \mathrm{Cu} W P$ & $210.39 \mathrm{a}$ & $>600$ & $0.75 \mathrm{~cd}$ & $13.05 \mathrm{a}$ \\
\hline Cuprous oxide $75 \%$ WP & $172.14 \mathrm{ab}$ & $>600$ & $0.36 \mathrm{e}$ & $3.32 \mathrm{bc}$ \\
\hline Copper calcium sulfate $20 \% \mathrm{WP}$ & $223.15 \mathrm{a}$ & $>600$ & $0.80 \mathrm{~cd}$ & $5.38 \mathrm{~b}$ \\
\hline Copper sulphate $25 \%$ Cu WP & $>600$ & $>600$ & $0.08 \mathrm{gh}$ & $0.65 \mathrm{e}$ \\
\hline Captan $50 \%$ WP & $>600$ & $>600$ & $0.48 \mathrm{de}$ & $1.35 \mathrm{de}$ \\
\hline Maneb 80\% WP & $42.58 \mathrm{c}$ & $>600$ & $1.21 \mathrm{c}$ & $27.52 \mathrm{a}$ \\
\hline Mancozeb $80 \%$ WP & $60.61 \mathrm{c}$ & 327.27 a & $6.74 \mathrm{~b}$ & $>32$ \\
\hline Folpet 50\% WP & $2.73 \mathrm{e}$ & $>10$ & $0.10 \mathrm{fg}$ & $0.59 \mathrm{e}$ \\
\hline $\begin{array}{c}\text { Folpet } 30 \%+\text { Cuprous oxide } 10 \%+ \\
\text { Copper calcium sulfate } 10 \% \mathrm{WP}\end{array}$ & $8.17 \mathrm{~d}$ & $>10$ & $0.14 \mathrm{f}$ & $1.77 \mathrm{~cd}$ \\
\hline Difenoconazole 25\% EC & $2.14 \mathrm{e}$ & $>10$ & $17.01 \mathrm{a}$ & $>32$ \\
\hline Kresoxim- methyl 50\% WG & $0.54 \mathrm{f}$ & $>10$ & $0.004 \mathrm{i}$ & $0.04 \mathrm{~g}$ \\
\hline $\begin{array}{c}\text { Pyraclostrobin } 10 \%+\text { Boscalid } 20 \% \\
\text { WG }\end{array}$ & $0.12 \mathrm{~g}$ & $>10$ & $0.002 \mathrm{j}$ & $0.01 \mathrm{~h}$ \\
\hline Benomyl 50\% WP & $0.11 \mathrm{~g}$ & $0.89 \mathrm{~b}$ & $0.05 \mathrm{~h}$ & $0.15 f$ \\
\hline
\end{tabular}

\footnotetext{
${ }^{1} \mathrm{WP}$, wettable powder; WG, water dispersible granule; EC, emulsifiable concentrate; EW, emulsion oil in water; $\mathrm{SL}$, soluble. The dose ranges evaluated in the different trials were: from 50 to 600 for mycelial growth in the first eight fungicides, from 0.01 to 10 for mycelial growth in the remaining ones, and from 0.0001 to 32 for conidial germination in all fungicides. ${ }^{2} \mathrm{EC}_{50}$ : effective concentration $\left(\mathrm{mg} \mathrm{L}^{-1}\right)$ inhibiting $50 \%$ of mycelia growth or conidial germination. ${ }^{3} \mathrm{EC}_{90}$ : effective concentration $\left(\mathrm{mg} \mathrm{L}^{-1}\right)$ inhibiting $90 \%$ of mycelia growth or conidial germination. ${ }^{4}$ Means in a column followed by the same letter do not differ significantly according to Fisher's protected least significant different (LSD) at $p=0.05$.
}

\subsubsection{Effect of Fungicides on Conidial Germination}

Most fungicides are highly effective at inhibiting conidial germination. Pyraclostrobin + boscalid, kresoxim-methyl, benomyl and copper sulphate obtained the lowest values of $\mathrm{EC}_{50}\left(<0.1 \mathrm{mg} \mathrm{L}^{-1}\right)$, while mancozeb and difenoconazole showed the highest $\mathrm{EC}_{50}\left(>5 \mathrm{mg} \mathrm{L}^{-1}\right)$. In relation to the $\mathrm{EC}_{90}$ values, only those of difenoconazole and mancozeb were above the highest dose tested (Table 3).

\subsection{Effect of Fungicides and Application Times in a Naturally Infected Orchard}

Trial I. In general, the incidence of CLSO was low during the two years of the trial and gradually decreased from the first to the last evaluation for all fungicidal treatments, but there was no such decrease in the control treatment $(p<0.001)$. No CLSO incidence was observed in the last evaluation with four of the five fungicides. Among the fungicides, difenoconazole + cuprous oxide exhibited the lowest decrease in CLSO incidence (Figure 3). The AUDPCs of all fungicides were lower than those of the control $(p<0.001)$. 


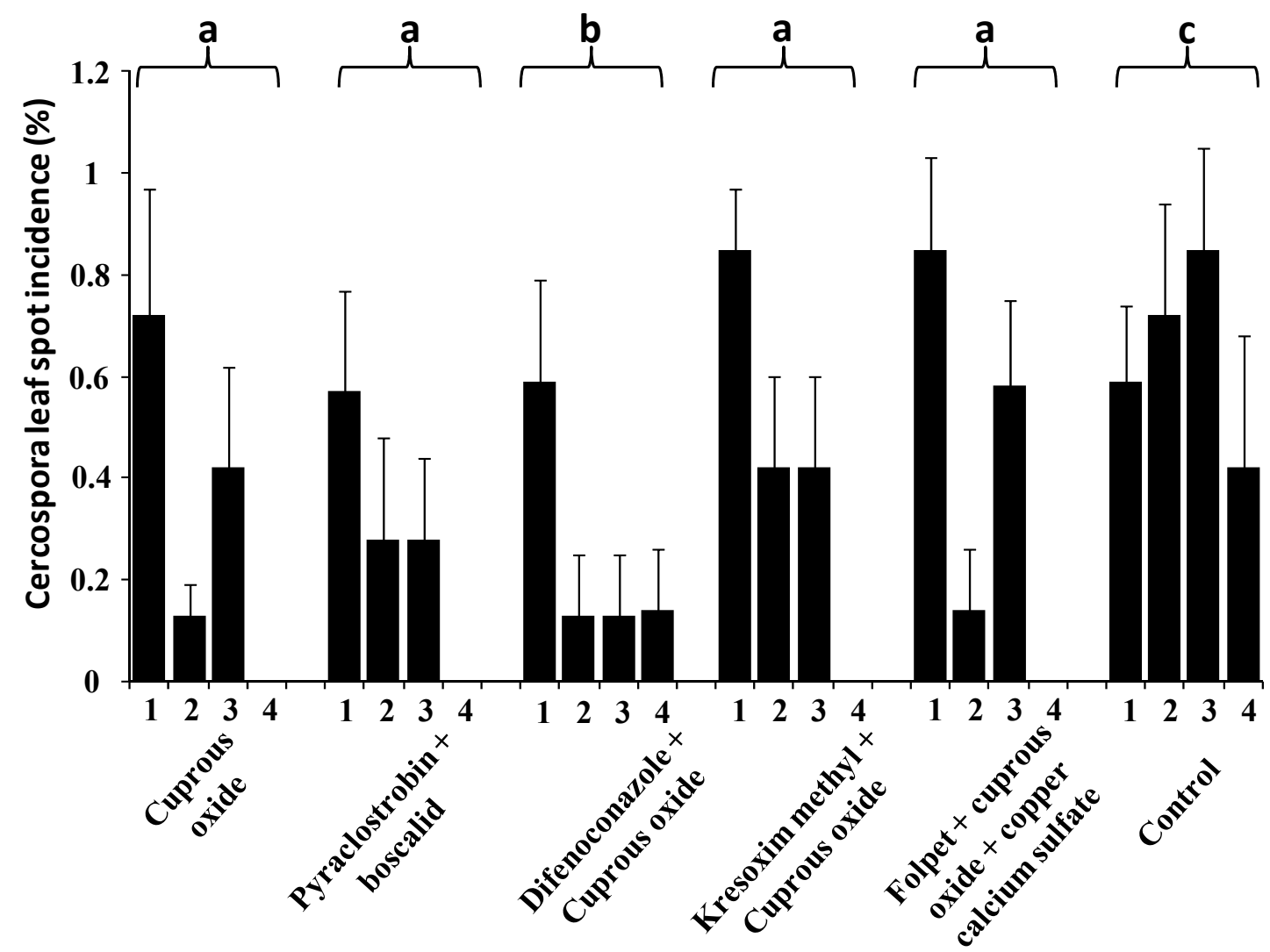

Figure 3. Incidence of cercospora leaf spot of olive (CLSO) at the four sampling times (1 = May 2003, $2=$ November 2003, 3 = March 2004 and $4=$ May 2004) in olive trees treated with different fungicides. Three applications per treatment were performed in March, May and October. Columns represent the average of 14 olive trees. Vertical bars are the standard error (SE) of the means. Fungicides with the same letter did not show differences in the reduction in CLSO incidence among the first and the last evaluation according to Fisher's protected LSD test at $p=0.05$.

Trial II. No CLSO incidence was observed in the last evaluation, with five of the seven timings of fungicide application (Figure 2). The CLSO incidence decreased at the end of the experiment but in different amounts. All the timings of fungicide applications reduced the CLSO incidence with respect to the control $(p<0.001)$. Applications in March and October were more effective than those in May (Figure 4). 


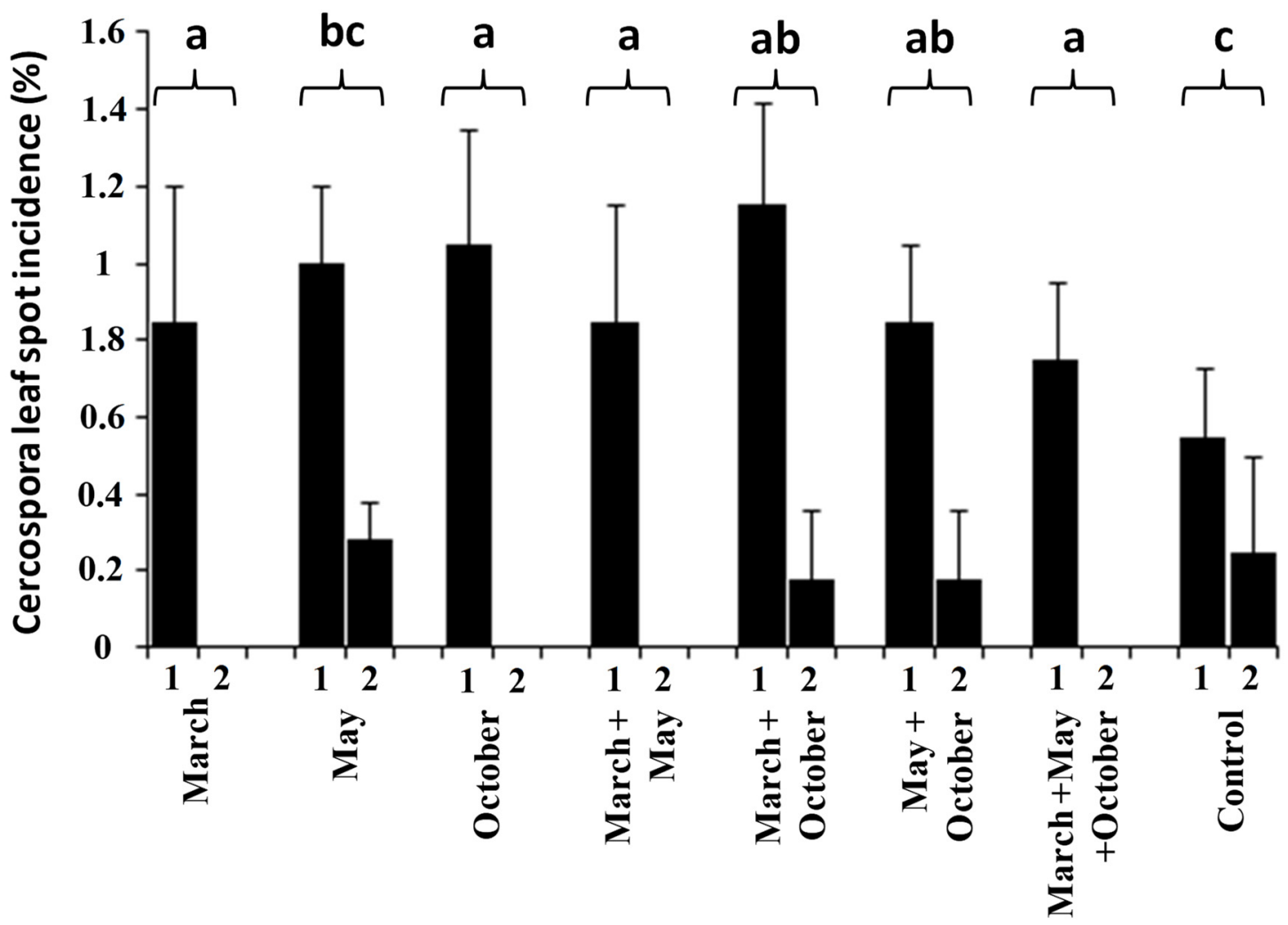

Figure 4. Incidence of cercospora leaf spot of olive (CLSO) at the beginning (May 2003) and at the end (May 2004) of Trial II for each fungicide application timing. All olive trees were treated with copper oxide (Nordox ${ }^{\circledR}$ super 75 ). Columns represent the average of the evaluations conducted in 14 olive trees. Vertical bars are the standard error of the means. Annual treatment times with the same letter did not show differences in reduction in CLSO incidence among the evaluations according to Fisher's protected LSD test at $p=0.05$.

\subsection{Effectiveness of Management Strategies against P. cladosporioides}

There was an important reduction in the number of FAs over the four years of the study with both the conservative (123 FAs, $15.8 \%$ reduction) and risky strategies (98 FAs, 32.9\% reduction) with respect to the traditional strategy (146 FAs) $(p=0.001)$. This reduction was greater when only the number of applications with copper-based fungicides was measured $(32.0 \%$ and $50.0 \%$ for the conservative and risky strategy, respectively) ( $p=0.003)$. The reduction in the number of FAs was variable, depending on the selected orchard (Table 4) and the season (Figure 5). For instance, the FA reduction using the conservative or risky strategies was $60.1 \%$ or $39.9 \%$, respectively, in orchard 8 . In contrast, the conservative strategy increased the number of FAs by $14.6 \%$ in orchard 10. Since the 2014/2015 season, the reduction in applications in the directed strategies was lower than those in the other strategies, especially due to the increase in CLSO incidence (Figure 6). 
Table 4. Relationship of the average number of fungicide applications (FA), incidence of cercospora leaf spot of olive (CLSO incidence) and Index of Fungicide Application Efficacy (IFAE) per each orchard and management strategy.

\begin{tabular}{|c|c|c|c|c|c|c|}
\hline & Orchard & Strategy & FA $^{1}$ & CLSO Incidence $(\%)^{2}$ & IFAE $^{3}$ & RIFAE $^{4}$ \\
\hline \multirow[t]{3}{*}{1} & \multirow[t]{3}{*}{ El Cañuelo } & Traditional & 1.75 & $0.49 b^{5}$ & 56.86 & \\
\hline & & Conservative & 1.50 & $1.04 \mathrm{a}$ & 65.97 & 1.16 \\
\hline & & Risky & 1.50 & $0.87 \mathrm{a}$ & 66.09 & 1.16 \\
\hline \multirow[t]{3}{*}{2} & \multirow[t]{3}{*}{ El Realengo } & Traditional & 2.25 & $1.87 \mathrm{a}$ & 43.61 & \\
\hline & & Conservative & 2.25 & $1.87 \mathrm{a}$ & 43.61 & 1.00 \\
\hline & & Risky & 1.75 & $1.87 \mathrm{a}$ & 56.07 & 1.29 \\
\hline \multirow[t]{3}{*}{3} & \multirow[t]{3}{*}{ El Realengo } & Traditional & 2.00 & $1.85 \mathrm{~b}$ & 49.08 & \\
\hline & & Conservative & 1.75 & $3.36 \mathrm{a}$ & 55.22 & 1.13 \\
\hline & & Risky & 1.00 & $2.74 \mathrm{ab}$ & 97.26 & 1.98 \\
\hline \multirow[t]{3}{*}{4} & \multirow[t]{3}{*}{ El Realengo } & Traditional & 3.67 & $0.84 \mathrm{a}$ & 27.02 & \\
\hline & & Conservative & 3.33 & $0.76 \mathrm{a}$ & 29.80 & 1.10 \\
\hline & & Risky & 2.00 & $1.74 \mathrm{a}$ & 49.13 & 1.81 \\
\hline \multirow[t]{3}{*}{5} & \multirow{3}{*}{ Fonte Dos Frades } & Traditional & 5.00 & $1.22 \mathrm{a}$ & 19.76 & \\
\hline & & Conservative & 4.00 & $1.22 \mathrm{a}$ & 24.70 & 1.25 \\
\hline & & Risky & 2.00 & $1.22 \mathrm{a}$ & 49.39 & 2.50 \\
\hline \multirow[t]{3}{*}{6} & \multirow[t]{3}{*}{ La Veguilla } & Traditional & 2.50 & $1.14 \mathrm{~b}$ & 39.54 & \\
\hline & & Conservative & 1.75 & $2.19 \mathrm{a}$ & 55.89 & 1.41 \\
\hline & & Risky & 1.25 & $2.07 \mathrm{a}$ & 78.34 & 1.97 \\
\hline \multirow[t]{3}{*}{7} & \multirow[t]{3}{*}{ Linares } & Traditional & 2.50 & $0.61 \mathrm{~b}$ & 39.76 & \\
\hline & & Conservative & 2.50 & $0.62 \mathrm{~b}$ & 39.75 & 1.00 \\
\hline & & Risky & 1.75 & $1.87 \mathrm{a}$ & 56.07 & 1.41 \\
\hline \multirow[t]{3}{*}{8} & \multirow[t]{3}{*}{ Los Cansinos } & Traditional & 3.33 & $0.04 \mathrm{a}$ & 30.02 & \\
\hline & & Conservative & 2.00 & $0.04 \mathrm{a}$ & 49.98 & 1.67 \\
\hline & & Risky & 1.33 & $0.04 \mathrm{a}$ & 75.16 & 2.50 \\
\hline \multirow[t]{3}{*}{9} & \multirow[t]{3}{*}{ Malena de Castro } & Traditional & 2.50 & $0.70 \mathrm{~b}$ & 39.72 & \\
\hline & & Conservative & 2.25 & $2.06 \mathrm{a}$ & 43.53 & 1.10 \\
\hline & & Risky & 2.00 & $2.53 \mathrm{a}$ & 48.74 & 1.23 \\
\hline \multirow[t]{3}{*}{10} & \multirow[t]{3}{*}{ Naranjilla } & Traditional & 2.33 & $0.84 \mathrm{~b}$ & 42.56 & \\
\hline & & Conservative & 2.67 & $2.03 \mathrm{a}$ & 36.69 & 0.86 \\
\hline & & Risky & 2.33 & $1.02 \mathrm{~b}$ & 42.48 & 1.00 \\
\hline \multirow[t]{3}{*}{11} & \multirow[t]{3}{*}{ Ribera Alta } & Traditional & 3.25 & $2.50 \mathrm{a}$ & 30.00 & \\
\hline & & Conservative & 3.25 & $2.89 \mathrm{a}$ & 29.88 & 1.00 \\
\hline & & Risky & 2.50 & $2.81 \mathrm{a}$ & 38.88 & 1.29 \\
\hline \multirow[t]{3}{*}{12} & \multirow[t]{3}{*}{ Todolivo } & Traditional & 3.00 & $0.04 \mathrm{a}$ & 33.32 & \\
\hline & & Conservative & 2.00 & $0.04 \mathrm{a}$ & 49.98 & 1.50 \\
\hline & & Risky & 1.67 & $0.04 \mathrm{a}$ & 59.86 & 1.80 \\
\hline \multirow[t]{2}{*}{13} & \multirow[t]{2}{*}{ Aljarafe } & Traditional & 4.33 & $0.81 \mathrm{~b}$ & 22.91 & \\
\hline & & Conservative & 3.33 & $1.48 \mathrm{a}$ & 29.59 & 1.29 \\
\hline
\end{tabular}


Table 4. Cont.

\begin{tabular}{|c|c|c|c|c|c|c|}
\hline & Orchard & Strategy & FA $^{1}$ & CLSO Incidence $(\%)^{2}$ & IFAE $^{3}$ & RIFAE $^{4}$ \\
\hline \multirow[t]{3}{*}{14} & \multirow[t]{3}{*}{ Los Ballesteros } & Traditional & 5.00 & $0.81 \mathrm{a}$ & 19.84 & \\
\hline & & Conservative & 5.00 & $0.60 \mathrm{a}$ & 19.88 & 1.00 \\
\hline & & Risky & 3.33 & $0.51 \mathrm{a}$ & 29.88 & 1.51 \\
\hline \multirow[t]{3}{*}{15} & \multirow[t]{3}{*}{ Cortijo de Guadiana } & Traditional & 2.50 & $0.21 \mathrm{a}$ & 39.92 & \\
\hline & & Conservative & 2.00 & $0.28 \mathrm{a}$ & 49.86 & 1.25 \\
\hline & & Risky & 1.50 & $0.18 \mathrm{a}$ & 66.55 & 1.67 \\
\hline \multirow[t]{2}{*}{16} & \multirow[t]{2}{*}{ Cortijo de Guadiana } & Traditional & 2.00 & $0.21 \mathrm{a}$ & 49.90 & \\
\hline & & Conservative & 0.50 & $0.31 \mathrm{a}$ & 199.38 & 4.00 \\
\hline
\end{tabular}

${ }^{1}$ Average of fungicide applications during the seasons in which each experimental orchard was maintained. ${ }^{2}$ Average of CLSO incidences calculated on the evaluations carried out during the whole period of each experimental field. ${ }^{3}$ IFAE: healthy tissue percentage (100-CLSO incidence) divided by FAs. The units are the percentage of healthy tissue per FA. Authors considered that the fungicides strategies with IFAE $<25$ (a fungicide application implies a protection lower than $25 \%$ of the all canopy leaves) did not achieve a successful control of CLSO. The IFAE average of the traditional strategy was lower (37.60) than the IFAE average of the conservative and risky strategies (53.27 and 67.42, respectively) $(p=0.011) .{ }^{4}$ Relative IFAE (RIFAE): IFAE of conservative or risky strategies divided by the IFAE of the traditional one. There were no significant differences between conservative and risky strategies $(p=0.175) .{ }^{5}$ For each orchard, means followed by the same letter are not significantly different according to the Fisher's protected LSD test $(p=0.05)$.

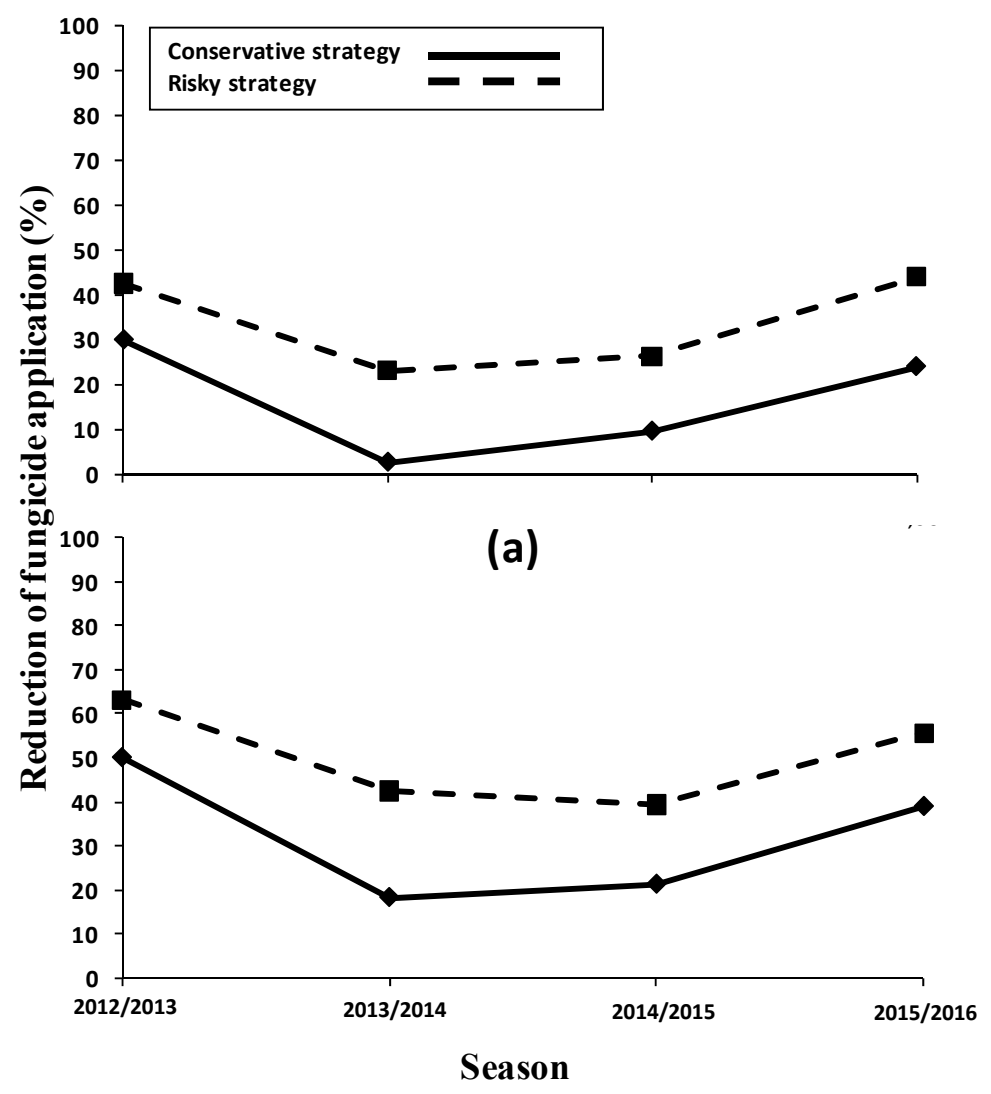

(b)

Figure 5. Four-season reduction in the total number of fungicide applications (a) and fungicide applications with copper as the active ingredient (b) in the conservative and risky strategies in comparison to the fungicide applications in the traditional strategy used as the control. There was a reduction in applications in terms of both the total and copper-based fungicides between the designed-by-authors strategies and the traditional strategy $(p=0.001)$. 


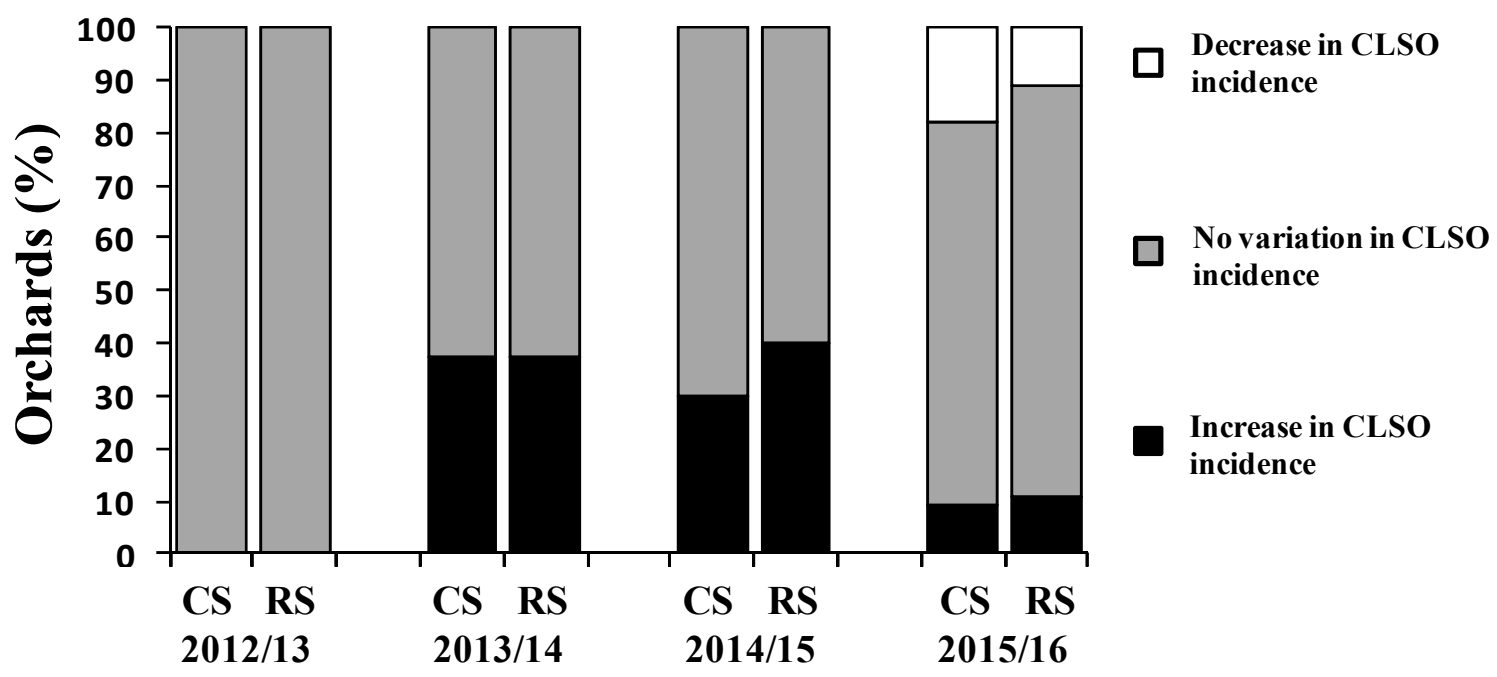

Figure 6. Four-season response of the conservative and risky strategies (CS and RS, respectively) in comparison to the traditional strategy used as the control. The percentage of orchards in which the incidence of cercospora leaf spot (CLSO) decreased (white area), remained (grey area) or increased (black area), based on Dunn test $(p=0.05)$, with respect to the traditional strategy is shown.

During the trial period, the average CLSO incidence in all orchards ranged from $0.04 \%$ (orchards 8 and 12, with the three strategies) to $3.4 \%$ (orchard 3, conservative strategy) (Table 4). The CLSO incidence was lower when the traditional strategy was conducted $(0.88 \%)$ in comparison to when the conservative and risk strategies were conducted $(1.32 \%$ and $1.36 \%$, respectively) ( $p=0.007)$. However, the CLSO incidence did not increase in $88.5 \%$ and $78.9 \%$ of all the evaluations when the conservative and risky strategies, respectively, were conducted. In the last season (2015/2016), a decrease in CLSO incidence was achieved with both strategies $(16.7 \%$ and $8.3 \%$ for conservative and risky ones, respectively) (Figure 4). The percentage of healthy tissue per FA, expressed by the IFAE, ranged from 19.84 (orchard 14, traditional strategy) to 199.38 (orchard 16, conservative strategy). The IFAE of the traditional strategy was lower (37.6\%) than that of the conservative and risky ones (53.3\% and $63.4 \%$, respectively) ( $p=0.011$ ). The relative IFAE (RIFAE) of the conservative strategies obtained in the orchards with low, mild and high risks of disease infection were 1.86, 1.16 and 1.08, respectively, although there were no significant differences between them $(p=0.175)$; with the risky strategy, these values were $1.72,1.66$ and 1.57 , respectively $(p=0.923)$. The highest and the lowest RIFAE were obtained in orchard 16 (4.00) and orchard $10(0.86)$, respectively, with the conservative strategy (Table 4).

\section{Discussion}

In this work, a total of 16 commercial fungicides, including inorganic copper compounds and organic compounds with systemic or protectant activity, were tested for their effect on mycelial growth and conidial germination of $P$. cladosporioides. Secondly, the most effective fungicides were selected for further studies under natural conditions to evaluate fungicide timing and management strategies. To our knowledge, few studies on chemical control against CLSO have been performed worldwide. Consequently, the current study provides helpful information to optimize fungicide applications by implementing the principles of the IPM $[31,39]$.

Several authors have performed previous studies indicating that copper is the most effective active ingredient against CLSO [40-43]. Nevertheless, systemic fungicides had the highest rates of mycelial growth inhibition based on our results. Among them, strobilurin compounds, pyraclostrobin + boscalid, and benomyl were able to inhibit the mycelial growth of P. cladosporioides even at very low doses. Difenoconazole and folpet also showed good inhibitory effects on mycelial growth, but copper-based 
compounds were the least effective, with high $\mathrm{EC}_{50}$ values. In comparison to protective fungicides (inorganic copper-based and organic fungicides), systemic fungicides provide a higher efficacy in inhibiting mycelial growth [44-46]. However, these differences between systemic and protective fungicides should not be directly extrapolated to field conditions because protective fungicides have a marked effect on conidial germination [47].

Regarding the fungicides effect on the conidial germination, the results varied in comparison with those observed for the inhibition of mycelial growth. The results revealed pyraclostrobin + boscalid mixture and the organic fungicide folpet as the most effective. Among the copper-based compounds, copper sulphate and cuprous oxide were the most effective against conidial germination. In this case, the $\mathrm{EC}_{50}$ values did not range as markedly as the $\mathrm{EC}_{50}$ values in terms of mycelial growth inhibition. The efficacy of copper sulfate has previously been reported under field conditions [15].

All the fungicides tested in naturally infected orchards reduced disease incidence. The efficacy of pyraclostrobin + boscalid was remarkable, even without the addition of copper-based compounds, because it allowed a reduction in the copper fungicide applications. Thus, it has been previously proposed that other active ingredients control CLSO, such as thiopron (a sulphur-based product) [15]. Moreover, the FA of an appropriate fungicide at optimal times is a key point in IPM. The results of this trial are not highly conclusive in terms of making decisions on FAs against CLSO because of the low CLSO incidence registered in the experiment, which are related to unfavorable climatic conditions for CLSO epidemics (i.e., lack of match between days with rainfall and $\mathrm{T}>10^{\circ} \mathrm{C}$ ). Perhaps because of this factor, a low CLSO incidence was observed even with only one FA per year, whereas other authors have cited two applications $[40,41,48]$ or even more than two FAs $[15,41,49]$ as required to control CLSO in susceptible olive cultivars. Nevertheless, our results suggest that FAs conducted in October or March are more effective than those conducted in May. FAs at the end of October would be useful for protecting the leaves at the beginning of conidial production under natural conditions [5], whereas treatments in February-March would have to act at the end of epidemic development, when temperature rises up and might concur with rain events. In contrast, weather conditions in May might be too hot and dry to promote P. cladosporioides infection given Mediterranean climate conditions [5].

The five rules of FA decision-making could be grouped based on two types of variables related to the presence of the pathogen (i and ii), one variable dependent on human intervention (iii) and two environmental variables related to temperature and rainfall (iv and v). Olive tree phenology was indirectly considered by matching rules of conservative and risk management in spring, when unprotected young leaves appear, which are more susceptible to CLSO [5]. Therefore, the four components of the disease tetrahedron were considered [50]. The results showed that copper applications could be strongly reduced by conservative and risky management strategies. The reduction in this active ingredient in crop protection is one of the goals of Directive 2009/128/EC of the European Union given the impact of copper on nature [22,51]. Moreover, an important reduction in the total amount of fungicides, including systemic ones, was also achieved. Despite the reduction in the number of FA, the percentage of evaluations in which CLSO incidence increased with respect to the traditional strategy was low. Although the average of the CLSO incidence in the traditional strategy $(0.88 \%)$ was lower than that in the conservative and risky ones (1.32\% and $1.36 \%$, respectively), these CLSO scarcely justify a higher number of FAs based on the concept of economic threshold of damages [52]. Thus, our results are helpful for olive growers in terms of establishing IPM against olive foliar diseases and decreasing the number of FAs, mainly with copper-based compounds.

Due to the lack of information with respect to CLSO incidence and yield or economic losses, ANOVA of dependent variables CLSO incidence, IFAE and RIFAE were performed to compare strategies. IFAE, from which RIFAE was calculated, showed better results with the strategies designed by the authors (conservative and risky ones) than those with the traditional strategy. Although without significant differences, RIFAE was higher in the orchards with low risk for the development of aerial olive diseases than in the other orchards. These results showed that a reduction in FAs is feasible, especially in olive orchards not located under very favorable conditions for CLSO development, 
such as geographical zones with mild temperatures, high rainfall and relative humidity or those close to troughs or poorly ventilated areas. Nevertheless, further studies are needed to (i) determine these favorable conditions and predict CLSO epidemics and (ii) identify accurate levels of CLSO incidence that justify the FAs. Both achievements may optimize decision making through advanced disease and crop-loss models [53] or fuzzy control systems [54], complementing or improving the results obtained in this study using decision-making rules.

Finally, this study shows the efficacy of several fungicides and provides helpful information about dates and rules for their application under field conditions. Furthermore, a reduction in fungicide application is possible when controlling CLSO through IPM. Future work on CLSO epidemiology and cultivar resistance could complement current knowledge about this disease.

Author Contributions: Conceptualization and design of experiments: J.R., L.F.R., A.Á. and A.T.; Performance of experiments; J.R., A.Á. and L.F.R.; Data analysis; J.R., A.Á. and A.T.; Writing: J.R.; Review and Editing; J.R., L.F.R., C.A.-B. and A.T.; Supervision: L.F.R. and A.T.; Funding Acquisition and Project Administration: A.T. All authors have read and agreed to the published version of the manuscript.

Funding: This research was supported by the project "Validación del modelo epidémico Repilos" funded by the Bayer CropScience and by the projects AGL2000-1725 and AGL2004-7495 from the Spanish Ministry of Science and Technology. C.A.-B. is the holder of a 'Juan de la Cierva-Incorporación' fellowship from MICINN.

Acknowledgments: We thank José María Manzanares (SC Fitoma), Todolivo S.L, and all the olive growers who yielded their orchards. The authors thank F. Luque for her skillful technical assistance.

Conflicts of Interest: The authors declare no conflict of interest.

\section{References}

1. Trapero, A.; López-Escudero, F.J.; Blanco, M.A. Enfermedades. In El Cultivo del Olivo, 7th ed.; Mundi-Prensa: Madrid, Spain, 2015; pp. 733-798. ISBN 9788484767145.

2. Ministerio de Agricultura. Pesca y Alimentación (MAPA). 2016. Available online: http://www.magrama.gob. es/es/agricultura/temas/producciones-agricolas/aceite-oliva-y-aceituna-mesa/aceituna.aspx\#para2 (accessed on 9 September 2019).

3. Del Moral, J.; Medina, D. El "repilo plomizo" del olivo causado por Cercospora cladosporioides Sacc., enfermedad presente en España. Bol. San. Veg. Plagas 1985, 12, 31-35.

4. Ávila, A.; Groenewald, J.; Trapero, A.; Crous, P. Characterisation and epitypification of Pseudocercospora cladosporioides, the causal organism of Cercospora leaf spot of olives. Mycol. Res. 2005, 109, 881-888. [CrossRef] [PubMed]

5. Ávila, A.; Romero, J.; Agustí-Brisach, C.; Roca, L.F.; Benali, A.; Trapero, A. Phenotypic and pathogenic characterization of Pseudocercospora cladosporioides, causal agent of cercospora leaf spot of olives. Eur. J. Plant Pathol. 2019, 156, 45-65. [CrossRef]

6. González-Fragoso, R. Botánica Criptogámica Agrícola, 1st ed.; Espasa-Calpe: Madrid, Spain, 1927; p. 321.

7. García-Figueres, F. Repilos del olivo: Ataque en fruto. Phytoma Esp. 1991, 25, 31-36.

8. Pappas, A.C. Mycocentrospora cladosporioides on olive in Greece. EPPO Bull. 1993, 23, 405-409. [CrossRef]

9. Hansen, H.N.; Rawlins, T.E. Cercospora fruit and leaf spot of olive. Phytopathologia 1944, 34, 257-259.

10. Bottalico, A.; Corda, P. Mycocentrospora cladosporioides from olive drupes in Sardinia. Plant Dis. 1995, 79, 320. [CrossRef]

11. Sergeeva, V.; Braun, U.; Spooner-Hart, R.; Nair, N. First report of Pseudocercospora cladosporioides on olive (Olea europaea) berries in Australia. Australas. Plant Dis. Notes 2008, 3, 24. [CrossRef]

12. Saccardo, P.A. Sylloge fungorum. Sylloge Fungorum 1886, 4, 1-87.

13. Farr, D.F.; Rossman, A.Y. Fungal Databases, U.S. National Fungus Collections, ARS, USDA. Available online: https://nt.ars-grin.gov/fungaldatabases/ (accessed on 2 May 2019).

14. Viruega, J.R.; Moral, J.; Roca, L.F.; Navarro, N.; Trapero, A. Spilocaea oleagina in olive groves of southern Spain: Survival, inoculum, production, and dispersal. Plant Dis. 2013, 97, 1549-1556. [CrossRef]

15. Viruega, J.R.; Roca, L.F.; Moral, J.; Trapero, A. Factors affecting infection and disease development on olive leaves inoculated with Fusicladium oleagineum. Plant Dis. 2011, 95, 1139-1146. [CrossRef] 
16. Triki, M.A.; Rhouma, A. First report of Pseudocercospora cladosporioides, the causal agent of Cercospora leaf spot of olive trees, in Tunisia. Phytopathol. Mediterr. 2008, 47, 262-265.

17. Nigro, F.; Sion, V. Integrated control of aerial fungal diseases of olive. In Proceedings of the 8th International Olive Symposium, Split, Croatia, 10-14 October 2016; Acta Hortic: Brussels, Belgium, 2018.

18. Obanor, F.O.; Walter, M.; Jones, E.E.; Jaspers, M.V. Greenhouse and field evaluation of fungicides for control of olive leaf spot in New Zealand. Crop Prot. 2008, 27, 1335-1342. [CrossRef]

19. Viruega, J.R.; Trapero, A.; Moreno, S. Efficacy of kresoxim-methyl against olive leaf spot caused by Spilocaea oleagina. Acta Hortic. 2002, 586, 801-804. [CrossRef]

20. Roca, L.F.; Viruega, J.R.; Avila, A.; Moral, J.; Marchal, F.; Romero, J.; Agustí- Brisach, C.; Trapero, A. El cobre: Materia activa básica en el control de las enfermedades del olivo. In Proceedings of the 14th Symposium de Sanidad Vegetal, Sevilla, Spain, 25-27 January 2017; COITAND: Sevilla, Spain, 2017.

21. Cacciola, S.O.; Faedda, R.; Sinatra, F.; Agosteo, G.E.; Schena, L.; Frisullo, S.; di San Lio, G.M. Olive anthracnose. J. Plant Pathol. 2012, 94, 29-44.

22. Vitanovic, E. Use of $\mathrm{Cu}$ fungicides in vineyards and olive groves. In Fungicides for Plant and Animal Diseases, 1st ed.; Intech Open: London, UK, 2012; pp. 279-298. ISBN 9789533078045.

23. Sanz-Cortés, F.; Martinez-Calvo, J.; Badenes, M.L.; Bleiholder, H.; Hack, H.; Yacer, G.; Meier, V. Phenological growth stages of olive trees (Olea europaea). Ann. Appl. Biol. 2002, 140, 151-157. [CrossRef]

24. Pérez-Rodríguez, P.; Paradelo, M.; Soto-Gömez, D.; Fernández-Calviño, D.; López-Periago, J.E. Modeling losses of copper-based fungicide foliar sprays in wash-off under simulated rain. Int. J. Environ. Sci. Technol. 2015, 12, 661-672. [CrossRef]

25. Vicent, A.; Armengol, J.; García-Jiménez, J. Rain fastness and persistence of fungicides for control of Alternaria brown spot of citrus. Plant Dis. 2007, 91, 393-399. [CrossRef]

26. Borkow, G.; Gabbay, J. Copper, an ancient remedy returning to fight microbial, fungal and viral infections. Curr. Chem. Biol. 2009, 3, 272-278.

27. Mackie, K.A.; Müller, T.; Kandeler, E. Remediation of copper in vineyards-A mini review. Environ. Pollut. 2012, 167, 16-26. [CrossRef]

28. Alavanja, M.C.R.; Hoppin, J.A.; Kamel, F. Health effects of chronic pesticide exposure: Cancer and neurotoxicity. Annu. Rev. Public Health 2004, 25, 155-197. [CrossRef]

29. Epstein, L. Fifty years since silent spring. Annu. Rev. Phytopathol. 2014, 52, 377-402. [CrossRef]

30. Gorlach, J.; Volrath, S.; Knauf-Beiter, G.; Hengy, G.; Beckhove, U.; Kogel, K.H.; Oostendorp, M.; Staub, T.; Ward, E.; Kessmann, H.; et al. Benzathiadiazole, a novel class of inducers of systemic acquired resistance, activates gene expression and disease resistance in wheat. Plant Cell 1996, 8, 629-643.

31. Rossi, V.; Caffi, T. Fungicide models are key components of multiple modeling approaches for decision-making in crop protection. Phytopathol. Mediterr. 2018, 57, 153-169.

32. Dhingra, O.D.; Sinclair, J.B. Basic Plant Pathology Methods, 2nd ed.; CRC Press: Boca Raton, FL, USA, 1995; p. 448. ISBN 978-0873716383.

33. Moral, J.; Trapero, A. Assessing the susceptibility of olive cultivars to anthracnose caused by Colletotrichum acutatum. Plant Dis. 2009, 93, 1028-1036. [CrossRef]

34. Moral, J.; Jurado-Bello, J.; Sánchez, M.I.; Oliveira, R.; Trapero, A. Effect of temperature, wetness duration, and planting density on olive anthracnose caused by Colletotrichum spp. Phytopathology 2012, 102, 974-981. [CrossRef]

35. Romero, J.; Agustí-Brisach, C.; Roca, L.F.; Moral, J.; González-Domínguez, E.; Rossi, V.; Trapero, A. A long-term study on the effect of agroclimatic variables on olive scab in Spain. Crop Prot. 2018, 114, 239-243. [CrossRef]

36. Barranco, D.; Fernández-Escobar, R.; Rallo, L. El Cultivo del Olivo, 7th ed.; Ediciones Mundi-Prensa: Madrid, Spain, 2017; p. 1008. ISBN 9788484767145.

37. Teviotdale, B.L.; Sibbet, G.S.; Harper, D.H. Several copper fungicides control olive leaf spot. Calif. Agric. $1989,43,30-31$.

38. Steel, R.G.D.; Torrie, J.H. Bioestadística: Principios y Procedimientos, 2nd ed.; MacGraw-Hill: Bogotá, Colombia, 1985; p. 622. ISBN 9684514956.

39. Rossi, V.; Caffi, T.; Salinari, F. Helping farmers face the increasing complexity of decision-making for crop protection. Phytopathol. Mediterr. 2012, 51, 457-479.

40. Ciccarone, A. Uno sguardo alla patologia dell'olivo nei paesi mediterranei. Options Mediterr. 1986, $24,71-79$. 
41. Gatica De Mathey, M.; Oriolani, E.J.A. Cercospora del Olivo, 1st ed.; INTA Estación Experimental Regional Agropecuaria Mendoza: Lujan de Cuyo, Argentina, 1983; p. 8.

42. Graniti, A.; Laviola, C. Sguardo generale alle malattie parassitarie dell'olivo. Inf. Fitopatol. 1981, 31, 77-92.

43. Sarasola, A.A. Nueva enfermedad del olivo en la Argentina causada por Cercospora cladosporioides Sacc. Rev. Fac. Agron. La Plata 1951, 28, 41-47.

44. Evans, E. Enfermedades de las Plantas y su Control Químico, 1st ed.; Labor: Barcelona, Spain, 1973 ; p. 307. ISBN 978-84-335-5809-1.

45. Moral, J.; Agustí-Brisach, C.; Agalliu, G.; Rodrigues de Oliveira, M.; Pérez- Rodríguez, M.; Roca, L.F.; Romero, J.; Trapero, A. Preliminary selection and evaluation of fungicides and natural compounds to control olive anthracnose caused by Colletotrichum species. Crop Prot. 2018, 114, 167-176. [CrossRef]

46. Sanchez-Pacheco, N. Evaluación In Vitro de Fungicidas Contra Spilocaea oleagina, Agente del Repilo del Olivo, Trabajo Fin de Carrera; ETSIAM, Universidad de Córdoba: Córdoba, Spain, 1999.

47. Campillo, R. Los productos cúpricos en la olivicultura actual. Phytoma Esp. 1998, 102, 159-167.

48. Cirulli, M.; Laviola, C.; Roberti, D. Avversità e difesa. In L'Olivo. Frutticoltura Anni 80; REDA: Roma, Italy, 1981; pp. 142-187.

49. Nigro, F.; Ippolito, A.; Gallone, P.; Carmignano, P.; Romanazi, G. Cercosporiosis of olive in Apulia and attempts to control the disease. Acta Hortic. 2002, 586, 773-776. [CrossRef]

50. Agrios, G.N. Plant Pathology, 5th ed.; Elsevier Academic Press: San Diego, CA, USA, $2005 ;$ p. 952. ISBN 9780080473789.

51. Yang, C.; Hamel, C.; Vujanovic, V.; Gan, Y. Fungicide: Modes of action and possible impact on non target microorganisms. ISRN Ecol. 2011, 1, 1-8.

52. Hunt, T.E.; Wright, R.J.; Hein, G.L. Economic Threshold for Today's Commodity Values; Adapted from Proceeding Crop Production Clinics 2019; University of Nebraska-Lincoln: Lincoln, NE, USA, 2009; pp. 93-96.

53. Savary, S.; Teng, P.S.; Willocquet, L.; Nutter, F.W. Quantificacion and modelling of crop losses: A review of purposes. Annu. Rev. Phytopathol. 2006, 44, 89-112. [CrossRef]

54. Chen, G.; Pham, T.T. Introduction to Fuzzy Sets, Fuzzy Logic, and Fuzzy Control Systems; CRC Press: Boca Ratón, FL, USA, 2000; p. 328. ISBN 9780367397883.

(C) 2020 by the authors. Licensee MDPI, Basel, Switzerland. This article is an open access article distributed under the terms and conditions of the Creative Commons Attribution (CC BY) license (http://creativecommons.org/licenses/by/4.0/). 